\title{
ANALYSIS OF IMMUNITY IN OSTEOSARCOMA AS A BASIS FOR DEVELOPMENT FOLLOWING THERAPY
}

\author{
Ferdiansyah $^{1 *}$, Mouli Edward ${ }^{1}$, Muhammad Hardian Basuki ${ }^{1}$, Kadek Seta Prawira ${ }^{2}$ \\ ${ }^{1}$ Staff of Orthopaedic and Traumatology Department, Faculty of Medicine, Universitas \\ Airlangga, Dr Soetomo General Hospital, Surabaya \\ ${ }^{2}$ Resident of Orthopaedic and Traumatology Department, Faculty of Medicine, Universitas \\ Airlangga, Dr Soetomo General Hospital, Surabaya \\ *Corresponding Author: Ferdiansyah, Staff of Orthopedic and Traumatology Department, \\ Faculty of Medicine, Universitas Airlangga, Jl. Mayjen Prof. Dr. Moestopo 6-8, Surabaya \\ E-mail: ferdyortho@yahoo.com
}

\begin{abstract}
ABSTRAK
Latar Belakang: Osteosarkoma adalah penyakit keganasan pada tulang. Semakin tinggi stadiumnya, prognosisnya semakin jelek. Prediktor yang digunakan untuk menentukan perkembangan osteosarkoma dari non invasif (stadium IIB) menjadi invasif (stadium III), melalui rasio makrofag-1(M-1) yang bersifat pro inflamasi (anti kanker) dengan makrofag-2 (M-2) yang bersifat anti inflamasi (pro kanker) masih belum jelas.
\end{abstract}

Tujuan: Menjelaskan peran rasio M-1 dengan M-2 pada perkembangan osteosarkoma non invasif menjadi invasif, dalam upaya mendapatkan prediktor yang dapat digunakan untuk pemilihan waktu pemberian terapi neoadjuvant.

Metode: Jenis penelitian observasional dengan rancangan cross sectional analitic study. Sampel penelitian semua blok parafin yang berisi jaringan penderita osteosarkoma, dikoleksi dalam kurun waktu 5 tahun. Jumlah sampel yang memenuhi kriteria inklusi diperoleh sebanyak 26 sampel, kemudian dibagi menjadi dua kelompok yaitu kelompok-I sebanyak 13 sampel stadium IIB dan kelompok-II sebanyak 13 sampel stadium III. Adapun variabel yang diukur adalah jumlah makrofag yang mengekspresikan TNF- $\alpha$ dan yang mengekspresikan IL-10 dengan metode imunohistokimia.

Hasil: Analisis data menggunakan uji Mann-Whitney, diperoleh hasil bahwa jumlah makrofag yang mengekspresikan TNF- $\alpha$ pada kelompok-I lebih besar dari pada kelompok-II $(p<0,05)$. Demikian juga makrofag yang mengekspresikan IL-10 pada kelompok-I lebih kecil dari pada kelompok-II $(\mathrm{p}<0,05)$.

Kesimpulan: Rasio M-1 yang dicerminkan oleh sel pengekspresi TNF- $\alpha$ dengan M-2 yang dicerminkan oleh sel pengekspresi IL-10, pada kelompok non invasif adalah 5:1. Sedangkan pada kelompok yang berkembang ke invasif adalah 1:6.

Kata kunci: osteosarkoma, inflamasi, M-1- M-2 polaritation, metastasis

\begin{abstract}
Background: Osteosarcoma is a malignant bone disease. Predictors which used to determine osteosarcoma from non-invasive (stage IIB) to invasive (stage III), through the ratio of macrophages-1 (M-1) which are pro-inflammatory (anti-cancer) with macrophages-2 (M-2) which have anti-inflammatory characteristic (pro cancer) is not clear yet.

Purpose: To elaborate the role of M-1 ratio with $\mathrm{M}-2$ in the development of non-invasive osteosarcoma become invasive, in effort to obtain predictors that can be used to the selection of neoadjuvant therapy time.

Methods: An observational study with cross sectional analytic study design. The sample of this research were all of paraffin blocks containing osteosarcoma patient tissue, collected within 5 years. The number of samples that met the inclusion criteria was 26 samples, and then divided into two groups, namely group-I as many as 13 stages IIB and group-II as many as 13 samples
\end{abstract}


of stage III. The measured variables are the number of macrophages that express TNF- $\alpha$ and those that express IL-10 by immunohistochemical methods.

Results: Analysis of the data using a Mann-Whitney test, and the results were obtain is the number of macrophages expressing TNF- $\alpha$ in group-I was greater than in group-II $(p<0.05)$. Likewise, macrophages that expressed IL-10 in group I were smaller than in group-II $(p<0.05)$. Conclusion: The M-1 ratio which reflected by TNF- $\alpha$ expression cells with M-2 as reflected by IL-10 expression cells in the non-invasive group is 5: 1 . Whereas in the group that develops to invasive is 1:6.

Keywords: osteosarcoma, inflammation, M-1- M-2 polarization, metastasis

\section{PENDAHULUAN}

Osteosarkoma (OS) adalah penyakit keganasan pada tulang. Berdasarkan data di RSUD Dr. Soetomo, angka kejadian osteosarkoma setiap tahunnya mengalami peningkatan. Berdasarkan data rekam medik tahun 2013-2014 ditemukan 30 kasus dan antara tahun 2015-2016 ditemukan 55 kasus. Metode terapi yang sering dilakukan untuk mengatasi penyakit keganasan adalah metode yang dikenal dengan neoadjuvant therapy. Berdasarkan laporan, dari 36 pasien yang mendapat neoadjuvant therapy, hanya 20 orang $(55,6 \%)$ yang memberikan respon baik. Tampaknya ada keterkaitan antara penurunan sistem imun penderita osteosarkoma dengan pemberian neoadjuvant therapy. ${ }^{1}$ Pada sistem imun sel yang paling berperan untuk menghancurkan sel kanker adalah sel NK (natural killer cell), sel ini aktif dan mampu menyerang sel kanker, bila ada rangsangan interferon gamma (IFN- $\gamma)$. Selain makrofag ada beberapa sel yang menghasilkan IFN- $\gamma$, diantaranya adalah limfosit Th-1. Namun sel tersebut akan menghasilkan IFN- $\gamma$ jika ada rangsangan dari interleukin-1 (IL-1) yang disekresikan oleh makrofag. ${ }^{2,3}$ Apabila terjadi penurunan IFN- $\gamma$, maka sel NK akan mengalami inaktivasi sehingga sel NK tidak mampu membunuh sel kanker melalui ikatan antara FasLigan (CD95R) di permukaan sel kanker dengan Ligan (CD95) di permukaan sel NK. ${ }^{4,5}$ Pada kanker yang invasif, terjadi polarisasi makrofag-1 (M-1) menjadi tumor associated macrophage (TAMs)/ makrofag$2(\mathrm{M}-2)^{6}$, kemudian TAMs/M-2 akan mensekresikan interleukin-10 (IL-10) ${ }^{7}$, selanjutnya IL-10 berperan sebagai anti inflamasi. ${ }^{8}$ Karena M-1 menghasilkan IFN $\gamma$, TNF- $\alpha$, dan IL-6 maka M-1 dikenal dengan makrofag proinflamasi, sedangkan M-2 menghasilkan IL-10 maka M-2 dikenal dengan makrofag anti inflamasi. ${ }^{9,10}$ Berdasarkan pemikiran tersebut, bila terjadi peningkatan M-1, maka terjadi pelepasan IFN $\gamma$ yang mengakibatkan peningkatan aktivitas sel NK, sehingga sel kanker dihancurkan oleh sel NK. M-1 merupakan makrofag yang bersifat anti kanker. Bila terjadi peningkatan aktivitas M-2, maka 
akan terjadi penekanan sel NK. Sehingga osteosarkoma dari non invasif (stadium IIB) berkembang menjadi invasif (stadium III), sehingga M-2 merupakan makrofag yang bersifat pro kanker. Karena itu apabila pada stadium IIB diberikan neoadjuvant therapy, maka sistem imun akan mengalami kemunduran yang mengakibatkan osteosarkoma mengalami progresif, sehingga perlu dipertimbangkan pemilihan waktu yang tepat pada pemberian neoadjuvant therapy. Untuk pemilihan waktu tersebut, diperlukan indikator yang dapat digunakan sebagai prediktor untuk menentukan batas perkembangan osteosarkoma dari non invasif (stadium IIB) yang memiliki sistem imun bersifat anti kanker, menjadi invasif (stadium III) yang memiliki sistem imun bersifat pro kanker. Bila kondisi stadium osteosarkoma yang memiliki sistem imun dominan anti kanker diberi neoadjuvant therapy, maka kerusakan sistem imun akibat neoadjuvant therapy, mengakibatkan terjadinya progresivitas osteosarkoma. Salah satu upaya untuk mendapatkan prediktor tersebut adalah melalui rasio M-1 dengan M-2. Namun rasio M-1 dengan M-2 dalam menentukan kualitas sistem imun yang bersifat anti kanker belum ditemukan. Karena itu, bila rasio M-1 dengan M-2 ditemukan, maka hal ini sangat penting sebagai dasar rasionalisasi pemilihan waktu yang tepat pada pemberian neoadjuvant therapy.

\section{METODOLOGI PENELITIAN}

Penelitian ini merupakan penelitian observasional dengan rancangan cross sectional analitic study. Populasi pada penelitian ini adalah semua blok paraffin yang berisi jaringan dari penderita osteosarkoma yang diambil dari Laboratorium Patologi Anatomi FK Unair/RSUD Dr. Soetomo.

Sampel yang digunakan adalah blok parafin yang berisi jaringan dari penderita osteosarkoma dikoleksi dalam kurun waktu 5 (lima) tahun, yaitu dari tahun 2013-2017 yang memiliki kriteria sebagai berikut:

1. Usia : 10 - 45 tahun (sistem imun masih stabil).

2. Jenis kelamin: pria.

3. Stadium osteosarkoma IIB dan III.

4. Blok parafin yang masih dapat digunakan (jaringan yang tidak habis/blok parafin rusak).

Jumlah sampel yang memenuhi kriteria inklusi sebanyak 26 sampel. Kemudian dibagi dua kelompok, yaitu kelompok-I sebanyak 13 sampel stadium IIB dan kelompok II sebanyak 13 sampel stadium III. Adapun variabel yang diukur adalah jumlah makrofag yang mengekspresikan TNF- $\alpha$ dan makrofag yang mengekspresikan IL-10. 
Metode yang digunakan untuk pengukuran TNF- $\alpha$ dan IL-10 adalah metode imunohistokimia. Caranya, jaringan osteoarkoma yang telah tertanam pada blok parafin, disayat dengan microtome (Leyca, Model: RM-2125RTS) dengan ketebalan sayatan antara 4-6 mikron, kemudian sayatan tersebut diletakkan pada waterbath (Leyca, Model HI1210) pada temperatur $45^{\circ}-55^{\circ} \mathrm{C}$, selanjutnya diambil dengan glass slide (Biogear Microscpe slide premium polysine Coated). Setelah sayatan jaringan menempel dengan baik pada glass slide kemudian dilakukan deparaffinisasi sampai pada tahap proses dengan menggunakan air, setelah itu dibilas dengan fosfat buffer salin (PBS) kemudian dilakukan pewarnaan imunohistokimia. Untuk mendeteksi jumlah sel makrofag yang mengekspresikan TNF- $\alpha$, pada penelitian ini menggunakan antibodi monoclonal anti TNF- $\alpha$ abcam product (cat: ab199013). Sedangkan untuk menghitung jumlah makrofag yang mengekspresikan IL10 menggunakan antibodi monoclonal anti IL-10 Santa Cruz Biotech (cat: sc-8438). Penilaiannya menggunakan mikroskop cahaya Olymphus type CX31 (Model CX31RBSF), dengan pembesaran 400x yang dievaluasi 10 lapang pandang, setiap lapang pandang luasnnya $15.625 \mu^{2}$, dan hasilnya diambil dari nilai rerata. Untuk dokumentasi menggunakan kamera olymphus Camedia (Model C-4000ZOOM).

\section{HASIL DAN PEMBAHASAN}

Setelah dilakukan penghitungan jumlah makrofag yang menekspresikan TNF- $\alpha$ dan makrofag yang mengekspresikan IL-10 dengan menggunakan metode imunohistokimia yang dievaluasi dalam 10 lapang pandang (setiap lapang pandang luasnya $15625 \mu^{2}$ ), maka dari setiap sampel baik pada kelompok penderita osteosarkoma stadium IIB maupun stadium III, diperoleh hasil seperti yang tercantum pada Tabel 1 berikut:

Tabel 1. Distribusi data nilai rata-rata dan standar deviasi variabel TNF- $\alpha$. dan IL-10

\begin{tabular}{cccccc}
\hline No. & $\begin{array}{c}\text { Jumlah } \\
\text { Sampel }\end{array}$ & Stadium & Variabel & $\begin{array}{c}\text { Rata- } \\
\text { rata }\end{array}$ & $\begin{array}{c}\text { Standar } \\
\text { Deviasi }\end{array}$ \\
\hline 1 & 13 & IIB & TNF- $\alpha$ & 4,5308 & 1,08042 \\
2 & 13 & IIB & IL-10 & 0,5538 & 0,24703 \\
3 & 13 & III & TNF- $\alpha$ & 0,9154 & 0,22674 \\
4 & 13 & III & IL-10 & 4,2615 & 1,23054 \\
\hline
\end{tabular}

Setelah dilakukan uji normalitas dengan menggunakan uji KolmogorovSminornov, baik pada variabel $\mathrm{TNF}-\alpha$ maupun IL-10 pada jaringan osteosarkoma, diperoleh bahwa kedua variabel tersebut memiliki distribusi yang tidak normal $(\mathrm{p}<0,05)$. Oleh karena itu, uji beda yang digunakan dari kedua variabel adalah uji Mann-Whitney (Tabel 2 dan Tabel 3).

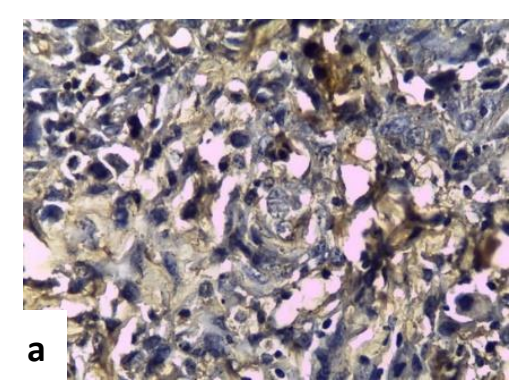




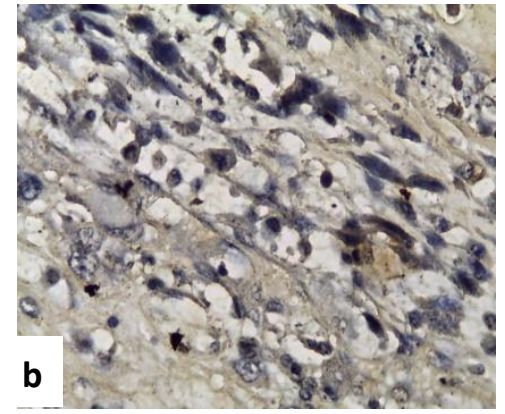

Gambar 1. Sayatan pada jaringan osteosarkoma dengan pewarnaan IHC menggunakan antibodi monoclonal terhadap TNFa. Sel yang mengekspresikan TNFa menunjukkan gambaran inti berwarna biru dan sitoplasma berwarna coklat, perbesaran 400x. (a) Stadium IIB, (b) Stadium III
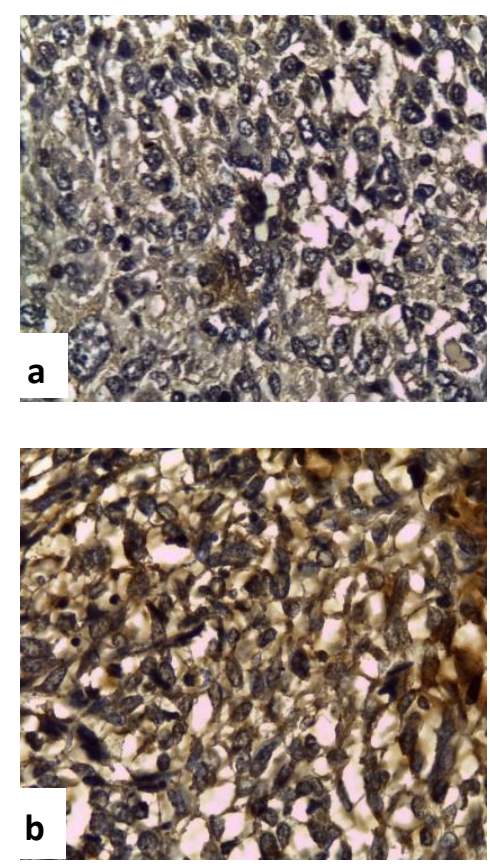

Gambar 2. Sayatan pada jaringan osteosarkoma dengan pewarnaan IHC menggunakan antibodi monoclonal terhadap IL-10. Sel yang mengekspresikan IL-10 menunjukkan gambaran inti berwarna biru dan sitoplasma berwarna coklat, perbesaran 400x. (a) Stadium IIB, (b) Stadium III
Tabel 2. Uji beda jumlah makrofag yang mengekspresikan TNF- $\alpha$ antara

osteosarkoma stadium IIB dengan stadium III dengan uji Mann-Whitney

\begin{tabular}{cccccc}
\hline n & \multicolumn{2}{c}{ Stadium IIB } & \multicolumn{2}{c}{ Stadium III } & p \\
& Mean & SD & Mean & SD & \\
\hline 13 & 4,5308 & 1,08042 & 0,9154 & 0,22674 & 0,000 \\
\hline
\end{tabular}

Tabel 3. Uji beda jumlah makrofag yang mengekspresikan IL-10 antara

osteosarkoma stadium IIB dengan stadium III dengan uji Mann-Whitney

\begin{tabular}{cccccc}
\hline n & \multicolumn{2}{c}{ Stadium IIB } & \multicolumn{2}{c}{ Stadium III } & p \\
& Mean & SD & Mean & SD & \\
\hline 13 & 0,5538 & 0,24703 & 4,2615 & 1,23054 & 0,000 \\
\hline
\end{tabular}

Osteosarkoma merupakan penyakit keganasan pada tulang. Penyakit keganasan oleh pembelahan sel yang tidak terkendali. Hal ini terjadi karena sel tersebut memiliki multi gene defect, yaitu gen yang menyandi protein yang mengatur siklus pembelahan sel seperti protooncogen dan tumosupressorgene. ${ }^{5,11,12}$ Apabila protooncogen mengalami mutasi, maka protein yang disandi bersifat overaktif, dan bila tumosupressorgene mengalami mutasi, maka protein yang disandi bersifat inaktif. ${ }^{5,12}$ Karena sel kanker merupakan klon sel yang memiliki gene defect, maka oleh sistem imun tubuh dianggap sebagai benda asing, sehingga sel kanker akan dihancurkan oleh sistem imun. Sistem imun yang berperan untuk menghancurkan sel kanker adalah sistem imun seluler, antara lain natural killer cell (sel NK). Adapun mekanisme kerja sel NK untuk menghancurkan sel kanker adalah melalui 
ikatan antara FasLigan (CD95R) di permukaan sel kanker dengan Ligan (CD95) di permukaan sel NK. Ikatan antara CD95R dengan CD95 pada permukaan sel kanker dengan sel NK mengakibatkan di dalam sitosol sel kanker terjadi aktivasi protein yang dikenal dengan fas associated death domain (FADD). Protein ini kemudian mengaktivasi caspase dan selanjutnya caspase akan mengaktifkan DNAse sehingga terjadi fragmentasi DNA dari sel kanker dan akhirnya sel kanker mengalami kematian/apoptosis. $^{4,5}$ Banyak faktor yang memengaruhi peningkatan aktivitas sel NK. Faktor yang paling penting adalah interferon gamma (IFN- $\gamma$ ), dimana sitokin ini dapat dihasilkan oleh beberapa sel antara lain limfosit T-helper-1 (TH-1), NK sel dan limfosit sitotoksik (CTL). Namun aktivasi dari setiap sel untuk memproduksi IFN- $\gamma$, diinduksi oleh makrofag. Sitokin yang dilepaskan oleh makrofag untuk menginduksi aktivitas sel TH-1, sel NK, dan CTL untuk memproduksi IFN- $\gamma$ adalah IL1dan IL-12. ${ }^{13}$ Faktor yang memengaruhi aktivitas makrofag antara lain patogen yang dikenal dengan pathogen associated molecule patern/PAMPs, atau sel debris yang dikenal dengan damage associated molecule patern/DAMps, dimana pembentukan DAMPs ini diakibatkan oleh trauma, inflamasi, iskemia atau malignansi. ${ }^{14}$ Akibat paparan PAMPs atau
DAMPs makrofag akan menghasilkan sitokin proinflamasi seperti IL-1, TNF- $\alpha$ dan IL-6 dan IL-8, kemudian IL6 dan TNF- $\alpha$, menginduksi sumsum tulang memproduksi sel darah putih sehingga terjadi leukositosis. ${ }^{15}$ Pada proses leukopoitik akan dibentuk juga sel NK. Peningkatan pembentukan sel NK di dalam tubuh penderita kanker, mengakibatkan sel kanker banyak mengalami kematian. Makrofag yang menghasilkan sitokin proinflamasi tersebut dikenal dengan makrofag-1 (M-1). Namun, sel kanker juga dapat menginduksi makrofag sehingga terjadi polarisasi makrofag. Makrofag yang diinduksi oleh sel kanker akan mengalami polarisasi menjadi tumor associated macropage (TAMs), dimana TAMs ini menghasilkan sitokin antiinflamasi yaitu IL10, TAMs tersebut dikenal juga dengan makrofag-2 (M-2). Makrofag koloni stimulating faktor (MCSF) berperan pada proses polarisasi M-1 menjadi M-2. ${ }^{16}$ Apabila terjadi peningkatan aktivitas M-1, maka sel NK akan aktif sehingga sel kanker tidak mengalami perkembangan. ${ }^{17,18}$ Sebaliknya, bila terjadi peningkatan M-2 maka sistem imun seluler akan ditekan dan akhirnya sel kanker menjadi progresif. ${ }^{19,20}$

Berdasarkan teori tersebut, maka pada penelitian ini peneliti mencoba melakukan penelitian pada kanker tulang (osteosarkoma/OS) yang mengaitkan antara fase non metastasis (stadium IIB) dengan 
osteosarkoma fase metastasis (stadium III) terhadap sistem imun seluler yaitu M-1 yang berperan untuk menghambat progresifitas kanker dan M-2 yang berperan untuk menginduksi progresifitas kanker. Adapun variabel yang diteliti adalah makrofag yang mengekspresikan TNF- $\alpha \quad$ yang mencerminkan aktivitas M-1 dan IL-10 yang mencermikan aktivitas M-2. Hasil dari penelitian tersebut ditunjukan pada gambaran sayatan histopatologi pada gambar 1 dan 2 yang memperlihatkan perbandingan aktivitas TNF- $\alpha$ dan IL-10 pada stadium IIB dan stadium III.

Pada Tabel 2, dapat dilihat jumlah makrofag yang mengekspresikan TNF- $\alpha$ antara kelompok osteosarkoma stadium IIB dengan stadium III, menunjukkan suatu perbedaan yang bermakna $(\mathrm{p}<0,05)(\mathrm{X}-\mathrm{IIB}=$ 4,5308; $\mathrm{SD}=1,08042)$ dan $(\mathrm{X}-\mathrm{III}=0,9154$; $\mathrm{SD}=0,22674)$. Jumlah makrofag yang mengekspresikan TNF- $\alpha$ pada jaringan osteosarkoma stadium III lebih kecil daripada jumlah makrofag yang mengekspresikan TNF- $\alpha$ pada jaringan osteosarkoma stadium IIB, karena TNF- $\alpha$ bersifat menekan fungsi dari M-2. ${ }^{21} \mathrm{Hal}$ ini menunjukkan bahwa pada osteosarkoma stadium IIB, terjadi peningkatan aktivitas M-1 yaitu makrofag pro inflamasi, dimana pada stadium ini makrofag selain melepaskan TNF- $\alpha$ juga melepaskan IL1-1 untuk menginduksi Th-1 mensekresikan
IFN- $\gamma .{ }^{22}$ Kemudian IFN- $\gamma$ ini memicu terjadi peningkatan aktivitas sel NK, sehingga sel osteosarkoma dihancurkan oleh sel NK. Berdasarkan hal terebut, maka osteosarkoma stadium IIB tidak berkembang ke arah metastasis.

Hasil penelitian rasio M-1 dengan M-2 pada osteosarkoma ditinjau dari aspek proinflamasi yaitu jumlah makrofag yang mengekspresikan TNF- $\alpha$ antara penderita osteosarkoma stadium IIB dengan III dihitung berdasarkan (+2 SD) adalah (X-IIB $=4,5308 ; \mathrm{SD}=1,08042)$ dan $(\mathrm{X}-\mathrm{III}=$ 0,9154; $\mathrm{SD}=0,22674)$. Rerata makrofag yang mengekspresikan TNF- $\alpha$ pada osteosarkoma stadium IIB adalah: $4,5308+2(1,08042)=6,69$. Sedangkan rerata makrofag yang mengekspresikan TNF- $\alpha$ pada osteosarkoma stadium III adalah: $0,9154+2(0,22674)=1,37$. Jadi rasio TNF- $\alpha$ antara M-1 dan M-2 pada stadium IIB dengan stadium III adalah 5:1.

Pada Tabel 3 terlihat jumlah makrofag yang mengekspresikan IL-10 antara kelompok osteosarkoma stadium IIB dengan stadium III, berbeda secara bermakna yaitu $(\mathrm{p}<0,05)(\mathrm{X}-\mathrm{IIB}=0,5538$; $\mathrm{SD}=0,24703)$ dan $(\mathrm{X}-\mathrm{IIIB}=4,2615 ; \mathrm{SD}=$ 1,23054). Jumlah makrofag yang mengekspresikan IL-10 pada jaringan osteosarkoma stadium IIB lebih kecil daripada jumlah makrofag yang mengekspresikan IL-10 pada jaringan 
osteosarkoma stadium III. Karena itu, dapat disimpulkan bahwa IL-10 sangat berperan untuk menekan fungsi Th-1, sehingga jika Th-1 ditekan maka akan terjadi penurunan pembentukan IFN- $\gamma$ penurunan IFN- $\gamma$ ini mengakibatkan terjadinya inaktivasi sel $\mathrm{NK}^{23}$ Sel NK yang tidak aktif mengakibatkan sel kanker berkembang dan metastasis. Hal ini terjadi karena sel kanker dapat merekrut monosit perifer dalam upaya membantu perkembangannya, yaitu menginduksi monosit menjadi tumor associated macrophages (TAMs) atau menjadi makrofag anti inflamasi $(\mathrm{M}-2){ }^{24}$ Selanjutnya makrofag yang mengekspresikan IL-10 jumlahnya mengalami peningkatan. IL-10 merupakan sitokin yang bersifat anti inflamasi sehingga M-1 yang bersifat pro inflamasi akan dihambat yang mengakibatkan terjadinya penurunan sintesis IF- $\gamma .{ }^{25,26}$ Penurunan IF- $\gamma$ ini mengakibatkan sel NK tidak mampu melakukan tugasnya untuk membunuh sel kanker, dan akhirnya sel kanker mengalami peningkatan proliferasi yang berkembang ke arah metastasis. TAM (M-2) merupakan sel yang sangat berperan pada proses perkembangan dan metastase dari sel kanker, karena sel tersebut melepaskan beberapa mediator antara lain: faktor pertumbuhan, enzim proteolitik, dan macrophage chemotractan protein-1 (MCP-
1), yang berperan pada proses angiogenesis dan faktor migrasi/invasi dari sel kanker. ${ }^{24,27}$

Hasil penelitian rasio M-1 dengan M-2 pada osteosarkoma ditinjau dari aspek anti inflamasi yaitu berdasarkan jumlah makrofag yang mengekspresikan IL-10 antara penderita osteosarkoma stadium IIB dengan III adalah (X-IIB $=0,5538 ; \mathrm{SD}=$ 0,24703) dan (X-III $=4,2615 ; \mathrm{SD}=$ 1,23054), dihitung berdasarkan (+2SD), maka rerata osteosarkoma IIB adalah 0,5538 $+2(0,24703)=1,05$. Sedangkan rerata osteosarkoma III adalah 4,2615 + $2(1,23054)=6,72$. Jadi rasio IL-10, antara M-1 dan M-2 osteosarkoma stadium IIB dengan III adalah M-1 : M-2=1,05 : 6,72 = 1: 6 .

\section{KESIMPULAN DAN SARAN}

\section{Kesimpulan}

Dari analisis jaringan osteosarkoma stadium IIB dengan stadium III dapat disimpulkan bahwa Rasio M-1 dengan M-2 pada jaringan osteosarkoma stadium IIB adalah 5:1. Sedangkan Rasio M-1 dengan M-2 pada jaringan osteosarkoma stadium III adalah 1: 6 .

\section{Saran}

Rasio M-1 dengan M-2 pada penderita osteosarkoma stadium IIB adalah 5:1, pada kondisi ini tampaknya sel NK masih aktif untuk membunuh sel kanker. Karena itu pada stadium ini sebaiknya 
pemberian neoadjuvant therapy diberikan secara lokal dan dikombinasi dengan immuno modulator.

\section{REFERENSI}

1. Xu M., S. F.Xu., X. C. Yu. Clinical analisis of osteosarcoma patients treated with high-dosteosarkomae methotrexate-free neoadjuvant chemoterphy. J. Curr Oncol. 2014; 21(5): e678-e684.

2. Chuang Y., Brianne KK., Josteosarkomahua NL. Regulation the IL-10-driven macrophage phenotype under incoherent stimuli, Publish Online Sep, 26. J. Inate Immunol. 2016;22(8): 647-657.

3. Sudiana IK. Imunopatobiologi Molekuler cetakan pertama. Airlangga University Press. 2014; hal.12-14.

4. Gerald UF, Adrienne MG, Afshin S. Heat Shock and Regulation of Apoptosteosarkomais in Neural Cells, edited by Christine Richter-Landsberg. 2005; p.1-5.

5. Sudiana IK. Patobiologi Molekuler Kanker. Jakarta: Salemba Medika. 2008; hal. 50-53.

6. Kurahara H., Hiroyuki S., Yuko M., Kousei M., Hidetosteosarkomahi N., Fumitake K., Masahiko S., Shinichi U., Shoji N., Sonshin T. Significance of M2 polarized Tumor-Associated Macrophage in Pancreatic cancer. $J$. Surgical Research, Published Online 2009.

7. Wang R., Meng Lu, Jie Zhang, Sufeng C., Xiaoyang L., Ying Q., Haiquan C. Increased IL-10 expression in tumorassociated macropgage correlated with late stage of lung cancer. Published Online. May 20, J.Exp Clin Cancer Res. 2011;30(1): 62.

8. Yang J, Zhang L, Yu C. Monocyte and Macrophage Differentiation: Circulation Inflammatory monocyte as
Biomarker for inflammatory Diseases. ListBiomark resv. 2014; vol 2, no.1.

9. Weagel E, Curren S, Ping GL, Richard R, kim ON. Macrophage Polarization and Its Role in Cancer. J. Clin \& Cell Immun. 2015;6: 338

10. Sudiana IK. Hantaran Sinyal pada prosteosarkomaes Inflamasi cetakan pertama. Airlangga University Press;2017; hal.32-35, 62-63.

11. Chow AY. Cell cycle Control by oncogenes and tumor suppressor : Driving the transformation of normal Cells into Cancerous cell. J. Nature Education. 2010; 3(9): 7.

12. Weinberg. Oncogenes and Tumor Suppressor Genes. J. Clin Cancer. 1994; (44):160-170.

13. Feghali CA., Timothy M. Cytokines in Acute and Chronic Inflammation. J. Biosteosarkomacience.1997; vol.2 p.216.

14. Bianchi ME. DAMPs, PAMPs and alarmins : all we need to know about danger. J.Leuco Biol Banner. 2006; 81(1): 1-5.

15. Kuby. Immunology, $4^{\text {th }}$ edition, New York, WH Freeman and Company. 2000; p.386.

16. Italiani P, Diana B. From Monocyte to M-1/M-2 Macrophages: phenotypical vs Fuctional Differentiation. J. Fron Immunol. 2014;5: 514.

17. Jorine JLP Voss, Catriona AF, Sofia P, Lynsey M, Margaret P, John DP, Pam $\mathrm{H}$, Bruno G, Tom CF, Christopher DG. Modulation of Macrophage antitumor potential by apoptotic lymphoma cells. J. Cell Death and Differentiation. 2017; 24,971-983.

18. Zamai L., Cristina P., Prisco M., Giuliana G., Stefano P., Laura G., Lucio C. Marco V. NK cell and Cancer. $J$. Immunol. 2017; 178: 4011-4016.

19. Weigert A, Nico T, Andreas VK, Axel MJ, Helmut S, Gerd G, Bernhard B. Tumor cell Apoptosis Polarized Macrophages-Role of Sphingosine -1 phosphate. J. Mol Bio Cell. 2007; 18(10): 3810-3819. 
20. Li Yang, Yi Zhang. Tumor-associated macrophages: from basic research to clinical application. J. Hematol and oncol. 2017; 10:55.

21. Kratochvill F, Geoffrey N, Jessica MH, Lee AV, Amber MS, Daisuke K. TNF counterbalances the emergence of M-2 tumor macrophages. HHS publish. 2015;12(11): 1902-1914.

22. Martinez FO, Siamon G. 2014; F1000 Prine Publish online Mar 3, doi 10: 12703/p6-13.

23. Cooper GM. The Cell : A Molecular Approach. $2^{\text {nd }}$ edition, Sunderland, Bosteosarkomaton University, 2000.

24. Yuan Shih J., Ang Yuan, Jeremy JW., Chen, Pan-Chyr Yang. Tumor Associated Macrophage: It's Role in Cancer Invasion and Metastasis. $J$. Cancer Molecules. 2006;2(3): 101-106.

25. Shanker S I, Genhong C. Role of Interleukin $10 \quad$ Transcriptional Regulation in inflammation and Auto imun Diseases. J. Immunol. 2012; 32(1): 23-63.

26. Eddie WK, NamikoH, Dror SS, Scott S, Ruslan M. Anti inflammatory effect of IL-10 mediated by metabolic reprogramming of macrophages. Science. 2017; 356(6337):13-519.

27. Sica A. Tiziana S., Alberto M., Paulo A. Tumour associated macrophagea are distinct M-2 Polarised population promoting tumour progression: Potensial targets of anti cancer therapy. European. J.Cancer. 2006;42: 717-727. 